\title{
45. FISSION TRACK CHRONOLOGY OF BASALTIC GLASSES FROM DSDP LEG 37
}

\author{
W. S. Mitchell and F. Aumento, Department of Geology, Dalhousie University, Halifax, Nova Scotia, Canada
}

\begin{abstract}
Natural basaltic glasses recovered from Leg 37 of the Deep Sea Drilling Project have been dated by fission track methods. Close agreement in results indicates that the age of the oceanic crust drilled at Site 332 is $3.67 \pm 0.40$ m.y. The age of the crust at Site 335 is less well defined, the average of the three dates obtained from this site being $14.45 \pm 2.27$ m.y.
\end{abstract}

\section{INTRODUCTION}

Fragments of unaltered basaltic glass suitable for fission track dating were recovered from three holes drilled on Leg 37 of the Deep Sea Drilling Project. At Site 332 glassy rinds and brecciated glass fragments were recovered from both Holes $332 \mathrm{~A}$ and $332 \mathrm{~B}$. Basalts recovered from Site 335 were particularly rich in fresh glassy rinds even though this hole was drilled in oceanic crust thought to be considerably older than that at Site 332. Fragments of sideromelane are also found in baked nanno ooze sediments occurring as interbeds within the basalts at Site 335. These glass fragments are partially altered to palagonite, especially along fractures and around the margins (Figure 1), but the cores of the larger fragments have remained unaltered and vitreous and are thought suitable for dating purposes.

No glass fresh enough for fission track dating was obtained from either Sites 333 or 334 .

\section{METHODS OF FISSION TRACK DATING}

The basaltic glasses were dated using essentially the same techniques of fission track dating as described in detail by Fleischer and Price (1964). Care was taken to ensure that all the glasses received identical treatment during polishing and etching, an important factor in fission track counting on an absolute basis for the purpose of dating (Reimer, 1974).

Error limits imposed on the calculated ages result from the statistical counting error in natural, irradiated, and standard glasses, and are given as one standard deviation.

\section{ENVIRONMENTAL FACTORS AFFECTING FISSION TRACK RETENTION}

Various environmental effects such as temperature, chemical change, and mechanical deformation can cause significant annealing or fading of tracks over a period of time. Any of these factors operating either singly or in combination will normally result in erroneously low calculated ages.

Temperature-related track fading characteristics for glass crusts from pillow lavas have been investigated experimentally (Aumento, 1969) and are not considered to be a problem provided the temperature of the glass after formation remained close to the mean sea-floor temperature (approximately $4^{\circ} \mathrm{C}$ ). Temperatures measured in the Leg 37 drill holes are quite low at the surface, but increase with depth to a maximum of $14.5^{\circ} \mathrm{C}$ at the bottom of the deepest hole, 332B (Hyndman et al., this volume). Considerable temperature disturbance by frictional heating also occurs on penetration and removal of the drill bit. The recorded temperatures, though higher than the mean sea-floor temperature, probably do not cause significant track annealing as extrapolation of annealing conditions shows that tracks should be unaffected in $50^{\circ} \mathrm{C}$ environments for $10^{3}$ m.y. (Aumento, 1969). Therefore temperaturerelated annealing of tracks is not considered to have affected the accuracy of the fission track ages.

Chemical alteration by oxidation or migrating solutions could cause redistribution of uranium in geological samples. This would be expected to be more of a problem for minerals than for glass in which any large chemical changes should be accompanied by its devitrification; indeed uranium concentrations in palagonite rims are many orders of magnitude greater than in the fresh glass (Mitchell and Aumento, this volume).

Water concentration in glass of rhyolitic composition has been shown to affect fission track stability, especially with increased temperatures (Lakatos and Miller, 1972a, b). Basaltic glass from Hole 332A, Core 18, Section 1, contains only $0.62 \% \mathrm{H}_{2} \mathrm{O}$ total and even if it, or any of the other Leg 37 glasses did contain more water (up to $1 \%$ ), track stability would be guaranteed by low ocean floor temperatures and by the relatively young age of the samples.

Mechanical erasure of tracks is more difficult to evaluate and as yet has only been documented in lunar samples (Fleischer and Hart, 1973). Hydrostatic pressure is not considered to affect track retention (Fleischer, 1974), but shear deformation resulting from shock or high static shear stresses causes significant erasure of tracks in minerals (Fleischer and Hart, 1973). It is unlikely that any evidence of deformation would be seen in a glass and it seems quite probable that, under certain drilling conditions, sufficient shear stress could be created to cause some erasure of tracks. 


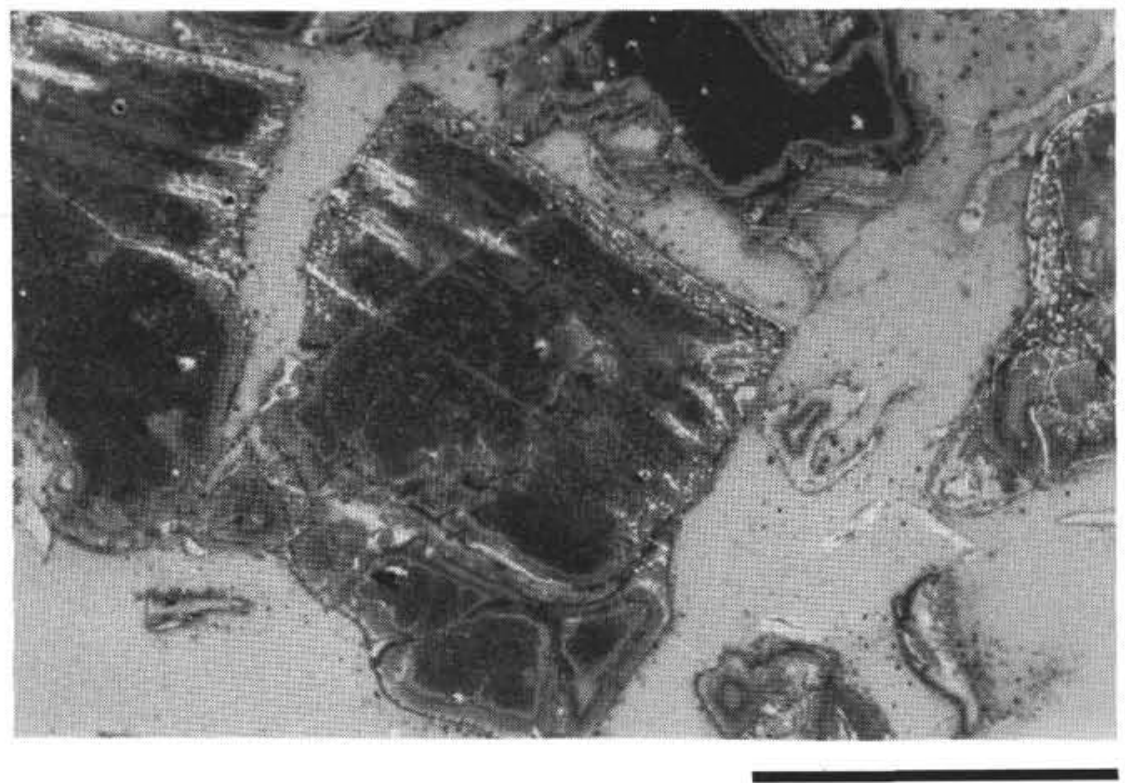

Figure 1. Palagonite rims surrounding sideromelane fragments enclosed in baked sediment. Scale bar represents $1 \mathrm{~cm}$.

Apart from any of these considerations, there is sometimes difficulty in distinguishing fission tracks in volcanic glass from small vesicles or, more important, from microlites in the glass which etch out in much the same way as tracks. Such problems in fission track dating can best be avoided by carefully choosing vitreous glass with as few vesicles and microlites as possible.

\section{RESULTS}

Results of fission track dating of Leg 37 basaltic glasses are tabulated in Table 1. Calculated ages of glasses from Hole $332 \mathrm{~A}$ range from 2.85 to 3.67 m.y. Good agreement in calculated fission track ages is obtained for all samples from Hole 332A with the excep- tion of Sample 26-2, \#2. Although this glass was obtained from the same core interval (26-2) as two other samples, it yielded a considerably lower age than any other determined for this hole. Only one small glass fragment of Sample 26-2, \#2 was used for counting purposes. As a consequence of the small area involved, less spontaneous tracks were counted than for the other samples, thus increasing the statistical error. On counting fission tracks in this sample, difficulty was also experienced in distinguishing fission tracks from small vesicles and other surface features in the glass, which, as previously described, can substantially affect the reliability of the calculated fission track age.

For these reasons the age determined for Sample 262 , \#2 has been excluded in assigning an average age of

TABLE 1

Fission Track Ages of Basaltic Glass, DSDP Leg 37

\begin{tabular}{|c|c|c|c|c|c|}
\hline $\begin{array}{c}\text { Sample } \\
\text { (Interval in } \mathrm{cm} \text { ) }\end{array}$ & $\begin{array}{l}\text { Spontaneous } \\
\text { Track Density } \\
\left(\text { Tracks } / \mathrm{cm}^{2} \text { ) }\right.\end{array}$ & $\begin{array}{c}\text { Induced } \\
\text { Track Density }\end{array}$ & $\begin{array}{l}\text { Neutron Flux } \\
\text { (nvt) }\end{array}$ & Age (m.y.) & $\begin{array}{c}\text { Uranium } \\
\text { Concentration } \\
(\mathrm{ppb})\end{array}$ \\
\hline \multicolumn{6}{|l|}{ Hole 332A } \\
\hline $\begin{array}{l}\text { 18-1 } \\
\text { Glass shards }\end{array}$ & 49.185 & $1.409 \times 10^{4}$ & $1.717 \times 10^{16}$ & $3.67 \pm .52$ & 80 \\
\hline $26-2, \# 2$ & 47.634 & $1.495 \times 10^{4}$ & $1.459 \times 10^{16}$ & $2.85 \pm .92$ & 107 \\
\hline $26-2, \# 3$ & 53.976 & $1.288 \times 10^{4}$ & $1.423 \times 10^{16}$ & $3.65 \pm .80$ & 90 \\
\hline $26-2, \# 18$ & 79.04 & $1.887 \times 10^{4}$ & $1.355 \times 10^{16}$ & $3.34 \pm .66$ & 145 \\
\hline \multicolumn{6}{|l|}{ Hole 332B } \\
\hline $8-1,50-51$ & 19.674 & $1.463 \times 10^{4}$ & $1.475 \times 10^{16}$ & $1.21 \pm .39$ & 100 \\
\hline $16-1,32-35$ & 12.09 & $2.859 \times 10^{3}$ & $1.423 \times 10^{16}$ & $3.68 \pm 1.18$ & 20 \\
\hline \multicolumn{6}{|l|}{ Site 335} \\
\hline $6-6,22-24, \# 2$ & 38.624 & $2.94 \times 10^{3}$ & $1.659 \times 10^{16}$ & $13.24 \pm 3.07$ & 18.6 \\
\hline $7-2,141-143$ & 45.297 & $2.53 \times 10^{3}$ & $1.493 \times 10^{16}$ & $16.37 \pm 4.8$ & 17.6 \\
\hline $10-1,145-147$ & 39.57 & $2.706 \times 10^{3}$ & $1.536 \times 10^{16}$ & $13.74 \pm 4.39$ & 18.4 \\
\hline
\end{tabular}



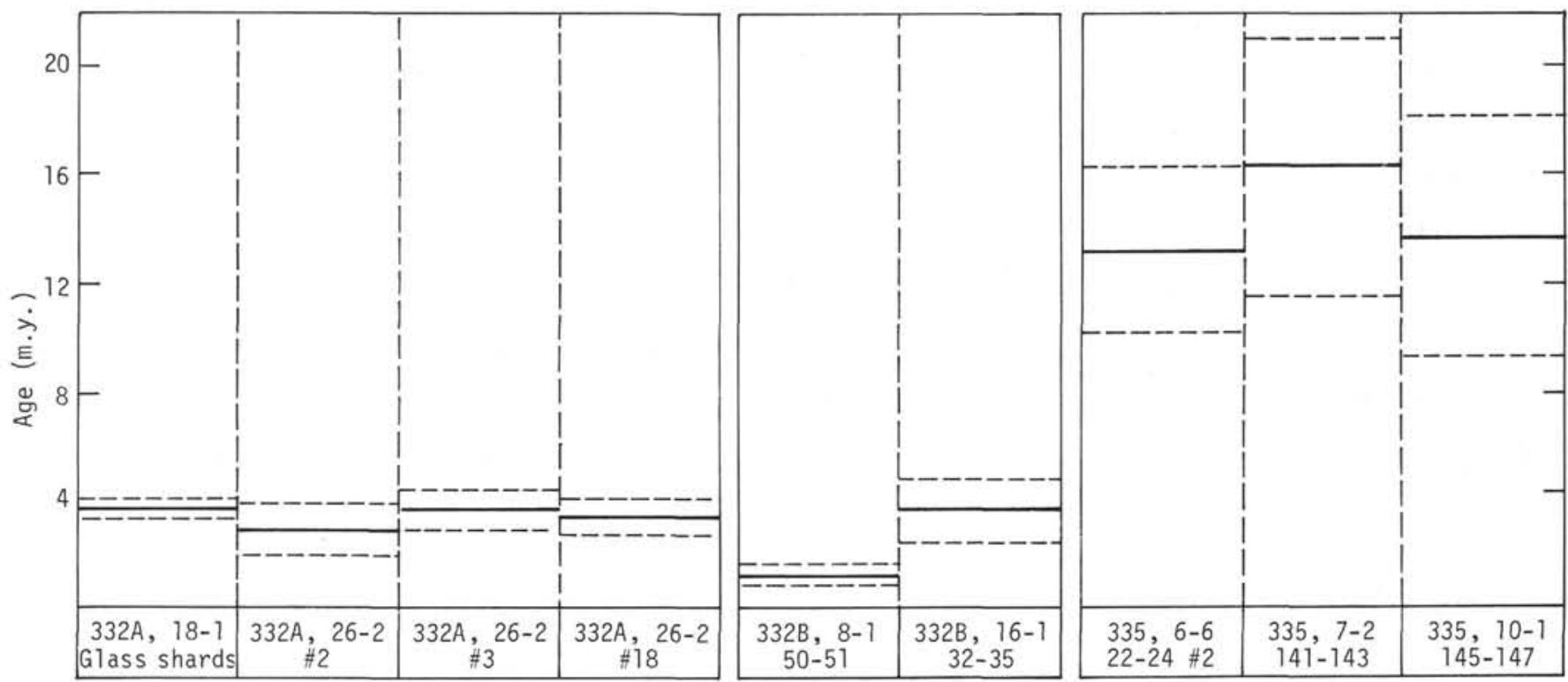

Figure 2. Graphic representation of fission track ages of basaltic glass, Leg 37. Calculated ages are represented by solid lines and error limits (one std. dev.) are shown by dashed lines.

$3.47 \pm 0.5 \mathrm{~m} . \mathrm{y}$. to the core interval $26-2$ and also in calculating the average age for Hole $332 \mathrm{~A}$, which was determined from three separate samples of glass and is given as $3.55 \pm 0.35$ m.y.

The two samples of glass from Hole 332B gave quite different ages of $1.21 \pm 0.39 \mathrm{~m} . \mathrm{y}$. and $3.68 \pm 1.18 \mathrm{~m} . \mathrm{y}$. Reasons for this discrepancy in results are not obvious. Both samples appeared vitreous and unaltered and since spontaneous tracks are equally well developed in both pieces of glass, there is no obvious evidence of track fading or annealing in the glass which gave the low age.

The difference in uranium content of the glasses may be of some significance. The higher concentration of uranium in the glass for which the lower age was determined may be an indication that some chemical redistribution has occurred, resulting in an anomalously low age. However, it should be noted that Hole 332A samples with high uranium content seem to give quite reliable ages, and available major element chemical analyses (Table 2) for some of the glasses show no large chemical differences.

It is worth noting at this point that the age of 3.68 $\pm 1.18 \mathrm{~m} . \mathrm{y}$. for glass from Hole $332 \mathrm{~B}$ corresponds very closely with ages of two samples from Hole $332 \mathrm{~A}$. Those samples are 18-1 and 26-2, \#3, which gave respective ages of $3.67 \pm 0.52$ m.y. and $3.65 \pm 0.88$ m.y. This correspondence in ages does not seem fortuitous, and we would suggest that $3.67 \pm 0.40 \mathrm{~m} . \mathrm{y}$., the average of the three ages which are in close agreement, can be considered to approach the "true" age of the basalts at Site 332.

Concentrations of uranium in the glasses from Site 335 reflect the chemical uniformity of the basalts recovered from this hole and are consistently low. Consequently large areas of glass were required for counting spontaneous tracks in each sample. Even so the high error limits are the direct result of low track counts.
Ages determined for the three samples from Site 335 range from 13.24 m.y. to 16.37 m.y. with an average for the three of $14.45 \pm 2.27$ m.y.

\section{COMPARISON OF FISSION TRACK, PALEONTOLOGICAL, AND PALEOMAGNETIC AGES}

Foraminifera in sediments from Hole $332 \mathrm{~A}$ indicate that the oldest sediments (Core 22) are near the early Pliocene-late Pliocene boundary, around 3.25 m.y. (Howe and Miles, this volume). Late Pliocene sediments (N 20 foram zone) of 3.0-3.25 m.y. are recorded in Hole 332B. Paleontological evidence from sediments at Site 332 therefore agrees well with the fission track ages of the basalts immediately below the sediments.

Paleomagnetic data for the negative magnetic anomaly in the area of Site 332 give an age of 3.32 to 3.78 m.y. The age of the magnetic source at Site 332, which lies close to the eastern edge of the negative magnetic anomaly, is given as $3.50 \pm 0.10$ m.y. This paleomagnetic age is therefore in close agreement with the fission track ages calculated from Site 332 natural glasses.

Sediments from Site 335, Core 5, immediately above the basalts appear to be of early late Miocene age (N 14 foram zone) of approximately 12 m.y. (Miles, this volume). The age of the magnetic anomaly source at Site 335 is less clearly delineated than at other sites, but is given as $16.5 \mathrm{~m} . \mathrm{y}$.

The average fission track age of 14.45 m.y. for basalts at Site 335 is considerably higher than the age of the oldest sediments, but is lower than the calculated age of the magnetic source at this site. It is worthy of note that the maximum fission track age of glass from Site 335 is close to the paleomagnetic age and may possibly be close to the true age of crust at this site. 
TABLE 2

Analyses of Glass Used for Fission Track Dating, Leg 37

\begin{tabular}{|c|c|c|c|c|c|c|c|}
\hline & $\begin{array}{c}332 \mathrm{~B}, \\
8-1,50-51\end{array}$ & $\begin{array}{c}332 \mathrm{~B}, \\
8-1,50-51\end{array}$ & $\begin{array}{c}332 \mathrm{~B} \\
16-1,32-35\end{array}$ & $\begin{array}{c}332 \mathrm{~A}, \\
26-2,13-14 \\
(\# 2)\end{array}$ & $\begin{array}{c}332 \mathrm{~A}, \\
26-2,25-26 \\
(\# 3)\end{array}$ & $\begin{array}{c}332 \mathrm{~A}, \\
18-1, \mathrm{CC}\end{array}$ & $\begin{array}{c}332 \mathrm{~A}, \\
26-2,132-135 \\
(\# 18)\end{array}$ \\
\hline $\mathrm{SiO}_{2}$ & 51.73 & 51.23 & 49.63 & 50.94 & 51.13 & 51.34 & 51.18 \\
\hline $\mathrm{TiO}_{2}$ & 1.17 & 1.25 & 0.84 & 1.26 & 1.28 & 1.00 & 1.23 \\
\hline $\mathrm{Al}_{2} \mathrm{O}_{3}$ & 14.91 & 14.54 & 15.61 & 14.93 & 14.76 & 14.78 & 14.86 \\
\hline $\mathrm{FeO}$ & 9.94 & 10.01 & 9.58 & 10.61 & 10.61 & 9.71 & 10.58 \\
\hline $\mathrm{MnO}$ & - & 0.46 & 0.46 & & & & \\
\hline $\mathrm{MgO}$ & 7.87 & 7.89 & 9.73 & 7.56 & 7.59 & 7.57 & 7.33 \\
\hline $\mathrm{CaO}$ & 12.37 & 12.16 & 11.98 & 11.93 & 11.95 & 12.59 & 11.90 \\
\hline $\mathrm{Na}_{2} \mathrm{O}$ & 2.02 & 2.01 & 2.09 & 2.11 & 2.07 & 2.08 & 2.14 \\
\hline $\mathrm{K}_{2} \mathrm{O}$ & 0.20 & 0.21 & 0.14 & 0.22 & 0.22 & 0.16 & 0.21 \\
\hline $\mathrm{P}_{2} \mathrm{O}_{5}$ & 0.10 & & & 0.14 & 0.11 & 0.10 & 0.13 \\
\hline $\mathrm{H}_{2} \mathrm{O}$ & - & & & - & & 0.62 & \\
\hline $\mathrm{S}$ & - & & & & & & \\
\hline Total & 100.31 & 99.76 & 100.06 & 99.70 & 99.72 & 99.95 & 99.56 \\
\hline
\end{tabular}

\section{CONCLUSIONS}

Fission track ages for glass from different parts of Holes 332A and 332B of DSDP Leg 37 agree quite well with the exception of two anomalously low ages. Reasons for the low ages are not immediately apparent but annealing caused by environmental effects, especially temperature, may have occurred.

The close correspondence in ages (3.68 m.y., 3.67 m.y., and 3.65 m.y.) of three samples recovered from this site suggests that the true age of the crust at Site 332 is $3.67 \pm 0.40$ m.y.

Ages determined for glass from Site 335 are less precise because of low uranium concentrations. The average age of oceanic crust at this site on the basis of fission track dating techniques is $14.45 \pm 2.27$ m.y.

No progressive increase in age of the basalts with depth could be detected in any of the holes.

\section{ACKNOWLEDGMENTS}

Financial support for the laboratory work was provided by the National Research Council of Canada. We are grateful for the technical assistance of $\mathrm{K}$. Taylor.

\section{REFERENCES}

Aumento, F., 1969. The Mid-Atlantic Ridge near $45^{\circ} \mathrm{N}$. V. Fission track and ferro-manganese chronology: Canadian J. Earth Sci., v. 6, p. 1431-1440.

Fleischer, R.L., 1974. Advances in fission track dating: General Electric Tech. Inform. Ser. Rept. No. 74CRD281.

Fleischer, R.L. and Hart, H.R., Jr., 1973. Mechanical erasure of particle tracks: a tool for lunar microstratigraphic chronology: J. Geophys. Res., v. 78, p. 4841-4851.

Fleischer, R.L. and Price, P.B., 1964. Glass dating by fission fragment tracks: J. Geophys. Res., v. 69, p. 331-339.

Lakatos, S. and Miller, D.S., 1972a. Evidence for the effect of water content on fission track annealing in volcanic glass: Earth Planet. Sci. Lett., v. 14, p. 128-130.

1972b. Fission track stability in volcanic glass of different water contents: J. Geophys. Res. v. 77, p. 69906993.

Reimer, G.M., 1974. Effects of progressive etching on fission track ages: Am. Nuc. Soc. Trans., v. 18, p. 87. 